\title{
Ideoiden ja todellisuuden tutkimus
}

Todellisuus muuttuu kaiken aikaa, sen toki tiedämme. Mutta mielestämme se ei ole syy jättää asioita tutkimatta. Miten ja missä määrin esimerkiksi yhteishankintakoulutus ajan kuluessa muuttuu, jää tulevien tutkimusten osoitettavaksi. Silloin on vertailun vuoksi hyvä olla olemassa tutkimustietoa myös yhteishankintojen alkuvaiheista.

Tohtori Räisäsenkin mainitsema Pauli Juuti (1994, ss. 98-101) kehottaa tutkimustuloksiinsa nojautuen työvoimakoulutuksen hankkijoita pitämään parempaa yhteyttä koulutustyöpaikoille. Samaan viittaavat myös omat tuloksemme. Työelämässä huonot yhteydet nähdään laajempanakin ongelmana, joka ei koske vain työvoimakoulutusta. Koulutussosiologian tutkimuskeskuksessa tehdyissä Työelämän koulutustarpeet -hankkeen tutkimuksissa työnantajien keskeinen kritiikki koskee vastavalmistuneiden osaamattomuutta, opettajien vieraantuneisuutta opettamansa alan käytännöstä sekä yleensä koulutusväen vähäistä kiinnostusta luoda ja pitää yhteyksiä työpaikoille. Tämän mm. työministeriön rahoittaman hankkeen loppuraportit (Naumanen \& Silvennoinen) ilmestyvät Työpoliittisia tutkimuksia -julkaisusarjassa tänä keväänä.

Olemme Heikki Räisäsen kanssa yhtä mieltä siitä, että asianmukaisesti toteutettuna työvoimakoulutusta olisi järkevää antaa enemmän työpaikoilla. Samaan hengenvetoon yhdymme myös siihen, että yleensäkin ammatillinen koulutus on Suomessa liiaksi eristetty koulujärjestelmän luokkahuoneisiin. jos ammatillisen koulutuksen keskeisenä tavoitteena pidetään työnteon oppimista, ihmiset olisi tarkoituksenmukaista kouluttaa pääasiassa työelämässä.

Ei ole kuitenkaan realistista uskoa koulutusjärjestelmän muutosta helpoksi toteuttaa. Ammatillisella koulutuksella kun on erityisesti näin massatyöttömyyden aikana varsinaiseen ammatinoppimiseen liittymättömiä tehtäviä, joista ei yhtäkkiä luovuta. On todennäköisempää, että koulutusta lähennetään työelämään päin lyhyin askelin. Kuten artikkelissamme toteamme, juuri yhteishankintakoulutus voi tuottaa arvokkaita kokemuksia sekä ammatillisen koulutuksen toteuttamisesta työelämässä että julkisen vallan ja yritysmaailman koulutusvastuun uudenlaisesta jaosta. Tämä on tutkimuksemme yksi päämotiivi.

Emme ole lainkaan sitä mieltä, että yhteishankintakoulutus on jotenkin periaatteessa huono. Päinvastoin, idea on mielestämme hyvä ja tavoiteltu suunta oikea. Koulutussosiologiseen tutkimustraditioon nojautuen olemme kuitenkin kiinnostuneempia kuvaamaan todellisuutta kuin ideoita sinänsä. Olemme tehneet tutkimusta siinä uskossa, että se on koulutuksen hankkijallekin tarpeellisempaa.

\section{Heikki Silvennoinen ja Kirsi Kuitunen}

